\title{
PERBANDINGAN METODE BACKPROPAGATION DAN LEARNING VECTOR QUANTIZATION (LVQ) DALAM MENGGALI POTENSI MAHASISWA BARU DI STMIK PALCOMTECH
}

\author{
Yarza Aprizal ${ }^{1}$, Rabin Ibnu Zainal ${ }^{2}$, Afriyudi $^{3}$ \\ ${ }^{1,2,3}$ Universitas Bina Darma \\ ${ }^{1}$ Email : yarza_afrizal@palcomtech.ac.id, ${ }^{2}$ Email : rabin.zainal@binadarma.ac.id, \\ ${ }^{3}$ Email : babeyudi@gmail.com
}

\begin{abstract}
ABSTRAK
Peneitian ini bertujuan untuk melakukan perbandingan metode backpropagation dan Learning Vector Quantization ( $L V Q)$ dalam menggali potensi mahasiswa baru di STMIK PalComTech. Perbandingan dalam penelitian ini melibatkan empat variabel masukan yang digunakan yang terdiri dari empat mata pelajaran dasar teknik informatika dan sistem informasi (matematika, pemrograman dasar, jaringan komputer dan dasar manajemen) yang kemudian menjadikan teknik informatika dan sistem informasi sebagai luaran, Untuk mendapatkan tingkat akurasi yang tinggi dalam penilitan ini, peneliti menggunakan beberapa variasi parameter yang akhirnyan menghasilkan akurasi terbaik dari kedua metode. Dari 120 data yang diuji menggunakan variasi data uji dan data latih yang selanjutnya diolah menggunakan variasi parameter learning rate dan jumlah epoch. Dari hasil pengujian diperoleh tingkat akurasi pengenalan pola pada metode backpropagation sebesar 99,17\% dengan variasi learning rate 0,1 dan jumlah epoch 100 , metode learning vector quantization didapat tingkat akurasi sebesar $96,67 \%$ dengan variasi learning rate 1 dan jumlah epoch 20. Dari hasil perbandingan metode Backpropagation lebih unggul dari segi akurasi sehingga menjadi metode yang tepat digunakan dalam menggali potensi mahasiswa baru di STMIK PalComTech.
\end{abstract}

\section{Kata kunci: Backpropagation, Jaringan Syaraf Tiruan, Learning Vector Quantization}

\begin{abstract}
The Research aimst to compare backpropagation and Learning Vector Quantization (LVQ) methods in exploring the potential of new students at STMIK PalComTech. Comparisons in this study involve four input variables used which consist of four basic subjects of informatics engineering and information systems (math, basic programming, computer networks and management bases) which then make informatics techniques and information systems as outputs, to get the accuracy level high in this study, the researchers used several variations of parameters which eventually produced the best accuracy of the two methods. From 120 data tested using variations in test data and training data which are then processed using variations in the learning rate parameters and epochs. From the test results obtained the level of accuracy of pattern recognition in the backpropagation method is $99.17 \%$ with a learning rate variation of 0.1 and epoch 100, the learning vector quantization method has an accuracy rate of $96.67 \%$ with a variation of learning rate 1 and epoch 20 From the results of the comparison the Backpropagation method is superior in terms of accuracy so that it becomes the right method to use in exploring the potential of new students at STMIK PalComTech.
\end{abstract}

\section{Keywords: Backpropagation, Artificial Neural Network, Learning Vector Quanitzation}

\section{PENDAHULUAN}

Pendidikan saat ini sudah menjadi prioritas utama, hampir semua orang memiliki cita-cita dan berlomba-lomba untuk meraih pendidikan yang setinggi-tingginya. Namun dalam menjalani proses pendidikan tidak jarang anakanak memutuskan diri untuk mengundurkan diri, [1] faktor ekonomi menjadi faktor yang paling dominan. Namun selain faktor ekonomi terdapat faktor lain yang mempengaruhinya, yaitu pemilihan jurusan.
Secara teoritis mahasiswa yang memiliki potensi yang tinggi terhadap satu bidang tertentu akan memiliki motivasi belajar yang tinggi pula, ini akan berbanding terbalik dengan mahasiswa yang kurang memiliki potensi pada bidang tersebut. Pada kasus ini pemetaan terhadap potensi tersebut akan berperan besar untuk menumbuhkan kepercayaan diri dan kenyamanan selama proses belajar mengajar berlangsung.

Ada beberapa metode yang digunakan dalam mengidentifikasi atau memprediksi 
potensi peserta didik dalam menentukan jurusan diantaranya adalah jaringan syaraf tiruan. Seiring dengan perkembangan teknologi telah banyak aplikasi-aplikasi yang dihasilkan menggunkan metode jaringan syaraf tiruan. Hal ini sejalan dengan penelitian yang akan dikaji kali ini, yakni pengenalan pola oleh Jaringan syaraf tiruan. Beberapa penelitian yang sifatnya membandingkan metode jaringan sayarf tiruan yang menjadi literatur dalam penelitian ini, Penelitan mengenai metode jaringan syaraf tiruan dalam mengklasifikasi penyakit Diabetes Millitus oleh Nurkhozin dengan metode jaringan syaraf yang digunakan adalah metode backpropagation dan learning vector quantization [2], kemudian penelitian mengenai perbandingan metode jaringan syaraf tiruan backpropagation dan learning vector quantization dalam mengenali Citra Barcode yang dilakukan oleh Fithri di tahun 2013[3]. Selanjutnya penelitian mengenai Perbandingan metode jaringan syaraf tiruan learning vector quantization dengan Kohnen Neural Network dalam mengenali pola tandatangan yang dilakukan oleh Prabowo, dkk[4].

Selain penelitian yang sifatnya membandingkan, peneliti juga memanfaatkan beberapa penelitian yang membahas mengenai penetuan jurusan untuk dimanfaatkan yang bertujuan meneyelsaikan permsalahan yang diangkat dalam penelitian kali ini, yakni menentukan metode yang lebih tepat digunakan dalam menggali potensi mahasiswa baru di STMIK PalComTech.

Penelitian yang dilakukan oleh Risky Meliawati dkk tahun 2015, penelitian ini bertujuan untuk menerapkan metode learning vector quantization dalam memprediksi penentuan jurusan di SMA PGRI 1 Banjarbaru. Hasilnya nilai akurasi yang didapat mendekati hasil sebenarnya dengan nilai iterasi yang berbeda yaitu 79,31\% dengan iterasi 60 dan 90 . Selain menggunakan iterasi yang berbeda penelitian ini juga menggunakan nilai alpha yang berubah, dengan nilai alpha 0,14 didapat akurasi $75,86 \%$. Maka dapat disimpulkan bahwa metode LVQ mampu melakukan prediksi pada penentuan jurusan di SMA PGRI 1 Banjarbaru [5].

Selanjutnya penelitian dari Dwi Kartini, Dkk (2017) dengan judul "Klasifikasi Kelulusan Mahasiswa Menggunakan Algoritma Learning
Vector Quantization". Klasifikasi kelulusan dalam penelitian ini adalah berdasarkan studi mahasiswa yakni bila mahasiswa menamatkan studi diatas 4,5 tahun dinyatakan tidak tepat waktu. Indeks Prestasi (IP) semester I, II, III, dan IV mahasiswa yang telah lulus juga menjadi salah satu perhatian dalam penelitian ini. Luaran penelitian ini berupa sistem diharapkan menjadi rekomendasi bagi dosen Pembimbing Akademik untuk memberikan arahan kepada mahasiswanya yang teridikasi tidak lulus tepat waktu yang pada akhirnya mengurangi jumlah mahasiswa yang Drop Out $(D O)$. Penelitian ini menghasilkan akurasi yang sesuai dengan data uji adalah $70 \%$ dengan maxepoch $=500$ dan $\alpha=0,5$ [6].

Kemudian penelitian dari Danang Aditya Nugraha dan Wiwik Retnowati (2015), luaran dari penelitian ini adalah sebuah aplikasi sistem pendukung keputusan, aplikasi dalam penilitian ini dibangun menggunakan aplikasi pemrograman java netbeans dan menggunakan metode jaringan syaraf tiruan backpropagation yang mengambil studi kasus di SMA Islam, dengan mempertimbangkan minat dan kemampuan siswa tidak hanya melihat dari nilai yang didapat siswa. Setelah dilakukan pengujian baik menggunakan data latih dan data uji, hasil error yang didapat setelah 1000 iterasi adalah 0.06440062529807385 , merupakan uji tekesci dengan persentase akurasi sebasar 75\% [7].

Penelitian oleh Arif Juarwanto, dkk (2009), penelitian ini bertujuan memprediksi penyakit THT menggunakan metode backpropagation dengan studi kasus di rumah sakit Mardi Rahayu Kudus. Hasil penelitian ini berdasarkan pengujian didapatkan tingkat akurasi sebesar $100 \%$ yang berarti jaringan syaraf tiruan yang dibuat dalam penelitian ini mampu mengenali pola THT dengan baik dengan MSE 0,001 [8].

Kusumadewi dalam bukunya menjelaskan bahwa jaringan syaraf tiruan terdiri dari 2 jenis metode pembelajaran. Metode yang pertama yaitu metode pembelajaran terawasi (supervised learning), sebuah metode jaringan syaraf tiruan termasuk kedalam metode pembelajaran terawasi apabila output yang diharapkan telah diketahui. Satu lagi metode pembelajaran tak terawasi (unsupervised learning), lain halnya dengan metode trawasi. Tidak memerlukan output merupakan ciri metode jaringan syaraf tiruan dengan metode pembelajaran tak terawasi. Berdasarkan uraian mengeneai metode 
pembelajaran pada jaringan syaraf tiruan, dapat disimpulkan bahwa metode pembelajaran terawasi lebih tepat digunakan dalam penelitian ini, hal ini juga dikuatkan dengan metode jaringan syaraf tiruan yang digunakan (backpropagation dan learning vector quantization) termasuk kedalam metode pembelajaran terawasi. Metode jaringan syaraf tiruan backpropagation memiliki keseimbangan jaringan untuk mengenali pola yang digunakan selama pelatihan dengan cara melakukan pelatihan jaringan serta kemampuan jaringan untuk memberikan respon yang baik terhadap pola masukan yang serupa (teteapi tidak sama) dengan pola yang digunakan selama pelatihan [10], lain halnya dengan metode learning vector quantization yang secara otomatis akan belajar mengklasifikasikan vektor-vektor masukan dalam melakukan pembelajaran pada lapisan kompetitif.

Metode backpropagation dan learning vector quantization jelas memiliki kelebihan dan kekurangan dari sisi prosespembelajarannya. Propagasi maju (forward) dan propagasi mundur (backward), kedua alur ini digunakan oleh metode backpropagation dalam perhitungan bobot. Sedangkan alur maju merupakan metode yang digunakan oleh learning vector quantization, dalam menentukan hasil pengenalan pola keduanya juga memliliki perbedaan. Berdasarkan literatur rivew serta kelebihan dan kekurang kedua metode, penelitian ini difokuskan untuk menentukan metode mana yang lebih tepat dalam pengenalan pola memprediksi potensi mahasiswa baru di STMIK PalComTech, maka penulis akan melakukan peneletian mengenai Perbandingan Metode Backpropagation dan Learning Vector Quantization ( $L V Q$ ) Dalam Menggali Potensi Mahasiswa baru di STMIK PalComTech.

\section{METODOLOGI}

Dari pendahuluan telah dijabarkan bahwa arah penelitian ini adalah membandingkan metode jaringan syaraf tiruan backpropagation dan learning vector quantization dalam menggali potensi mahasiswa baru di STMIK PalComTech. Dengan tujuan membandingkan tersebut maka metode yang digunakan dalam penelitian ini adalah metode komperatif dengan pendekatan kuantitatif. Data yang digunakan dalam penelitian ini didapat dari hasil potensi yang diajukan kepada mahasiswa baru di STMIK PalComTech dari tiga angkatan yang berbeda, ini ditujukan untuk mendapatkan data primer. Lainhalnya dengan data sekunder yang didapat dari publikasi yang relevan dengan penelitian kali ini. Soal tes potensi yang digunakan dalam penelitian ini dikembakngkan berdasarkan potensi program studi Teknik Informatika dan Sistem Informasi di STMIK PalComTech. Tahapan-tahapan dalam penelitian ini dapat dilat pada gambar 1:

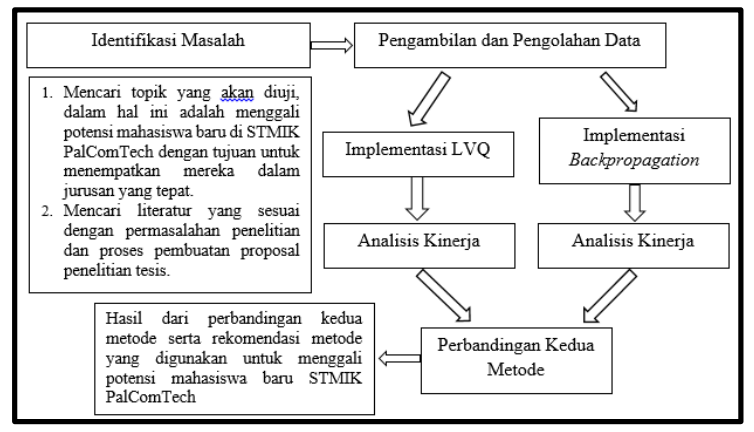

Gambar 1. Tahapan penelitian

Dari gambar 1 didapatlah penjelasan tahapan-tahapan penelitian sebagai beriktu:

1. Tahapan pertama adalah mengidentifikasi masalah yang diawali dengan mencari, mempelajari dan mengumpulkan informasi serta membaca artikel mengenai permasalahan yang akan diangkat didalam penelitian ini. Pemasalahan dalam hal ini adalah mencari metode terbaik berdasarkan akurasi untuk diterapkan dalam tes potensi di STMIK PalComTech,

2. Tahapan kedua yaitu mengambil data, penelitian ini menggunakan alat ukur berupa soal-soal tes potensi yang disusun berdasarkan potensi dari dua program studi yang di STMIK PalComTech (Sistem Informasi dan Teknik Informatika). Adapun data yang diperoleh berupa nilai dari hasil tes potensi (nilai matematika, nilai dasar manajemen, nilai jaringan komputer dan nilai pemrograman) yang nantinya digunakan sebagai imputan $\left(x_{1}, x_{2}, x_{3}\right.$, dan $x_{4}$ ) dan dipasahkan menjadi data uji dan data latih,

3. Tahapan yang ketiga adalah mengolah data dan transformasi data terhadap nilai hasil 
tes potensi yang dilakukan pada tahap sebelumnya, transformasi dilakukan sesuai dengan kebutuhan metode Backpropagation dan $L V Q$,

4. Tahapan akhir dalam penelitian ini adalah melakukan pengujian data training dan data uji menggunakan metode backpropagation dan $l v q$, kemudian analisis keakurasian kedua metode didapat dari pengujian kedua metode yang pada akhirnya dapat ditarik sebuah kesimpulan metode mana yang memiliki tingkat keakurasian lebih tinggi dari kedua jaringan syaraf tiruan tersebut (Backpropagation dan $l v q$ )

\section{A. Jaringan Syaraf Tiruan}

Salah satu medote untuk merepresentasikan buatan dari otak manusia yang selalu mencoba mensimulasikan suatu proses pembelejaran adalah pengertian dari jaringan syaraf tiruan, dalam memberikan sebuah gambaran mengenai jaringan syaraf tiruan yang rancang dan diterapkan menggunakan program komputer yang mampu menyesuaikan proses perhitungan selama proses pembelajaran yang mirip dengan kinerja otak manusia maka digunakanlah kata buatan. Puspitaningrum dalam bukunya Pengantar Jaringan Syaraf Tiruan mendegenisikan Artificial Neural Network sebagai alat yang digunakan untuk memecahkan masalah di bidang-bidang yang melibatkan pengelompokan dan pattern recognition (pengenalan pola) yang berada pada cabang ilmu Artificial Intelligence atau kecerdasan buatan [11]. Menurut menurut Fausett, jaringan syaraf tiruan merupakan sebuah sistem pemrosesan informasi yang memiliki karakteristik menyerupai jaringan syaraf biologis manusia[12]. Dari kedua definisi sebelumnya dapat disimpulkan bahwa Jaringan syaraf tiruan merupakan suatu alat untuk memecahkan masalah yang memiliki cara kerja yang mirip dengan jaringan syaraf biologis manusia.

\section{B. Konsep Dasar Jaringan Syaraf Tiruan}

Jaringan syaraf tiruan terdiri dari setiap pola yang diperoleh baik berupa input atau output yang akan diproses oleh neuron. Kumpulan neuron-neuron yang berada dalam lapisanlapisan disebut Neuron layers. Jaringan syaraf tiruan terdiri dari 3 (tiga) lapisan-lapisan penyusun yang dimuat dalam penelitian
Lesnussa dkk, adapun lapisan-lapisan penyusun tersebut adalah:

1. Lapisan input, unit-unit input merupakan sebuatan dari unit-unit yang berada didalam lapisan ini. Lapisan ini menggambarkan suatu permasalahan berdasarkan pola yang diterima berdasarkan inputan data dari luar,

2. Lapisan tersembunyi, unit-unit tersembunyi merupakan sebutan untuk unit-unit yang berada didalam lapisan ini. Didalam lapisan tersembunyi luaran atau output secara langsung tidak dapat diamati,

3. Lapisan output, unit-unit output merupakan sebutan untuk unit-unit yang berada didalam lapisan ini. Solusi dari jaringan syaraf tiruan terhadap suatu permasalahan merupakan output dari lapisan ini[13].

\section{Arsitektur Jaringan Syaraf Tiruan}

Dalam berbagai penerapannya, jaringan syaraf tiruan memiliki beberapa arsitektur. Jaringan syaraf tiruan dibagi menjadi 3 (tiga), ini dikutip dari Puspitorini yang dimuat didalam penelitian Lesnussa Y.A, dkk, yaitu:

1. Jaringan Layar Tunggal (single layer network).

Arisitektur jaringan syaraf tiruan yang termasuk dalam jaringan layar tunggal terdiri dari 1 (satu) layer input dan 1 layer ouput, neuron/unit yang berada didalam lapisan ini akan selalu terhubung dalam hal ini layer input akan selalu terhubung dengan layer output. Lapisan tersembunyi tidak terlalu memiliki pengaruh ini dikarenakan jaringan dengan arsitektur jaringan layer tunggal hanya menerima masukan yang langsung diproses menjadi luaran tanpa harus melewatinya. ADALINE, Hopfield, Perceptron merupakan contoh dari algoritma jaringan syaraf tiruan layar tunggal. Arsitektur jaringan layar tunggal ditunjukkan dalam gambar 2: 


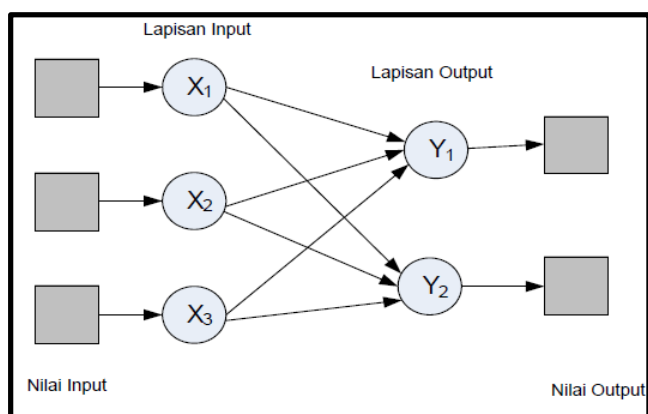

Gambar 2. Arsitektur Layar Tunggal

2. Jaringan layar jamak (multi layer network). Arsitektur jaringan layar jamak terdiri dari 3 (tiga) layer, yaitu layer masukan (input), layer tersembunyi, dan layer luaran (output), yang membedakannya dengan jaringan layer tunggal, jaringan dengan jenis ini dapat menyelesaikan masalah yang rumit namun akan cenderung lebih lama dalam proses pelatihannya.

Algoritma MADALINE, backpropagation, neocognitron merupakan beberapa algoritma yang menggunakan layar jamak. Gambar 3 menunjukan arsitektur jaringan layar jamak sebagai berikut:

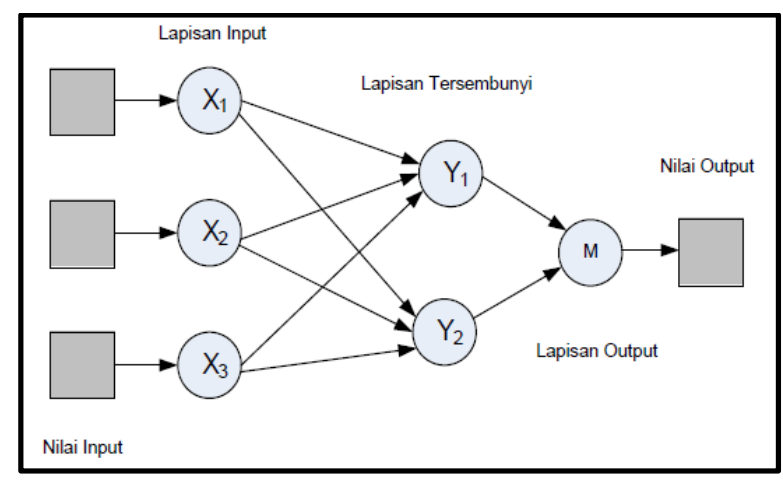

Gambar 3. Arsitektur Layar Jamak

3. Jaringan dengan lapisan kompetitif.

Didalam lapisan dengan jenis ini untuk mendapatkan hak menjadi aktif sekumpulam neuron yang ada harus bersaing, oleh karena itu jaringan ini disebut jaringan lapisan kompetitif. Algoritma Learning Vector Quantization (LVQ) merupakan algoritma yang menggunakan jaringan lapisan ini. Jaringan dengan lapisan kompetitif ditujukkan pada gambar 4, sebagai berikut:

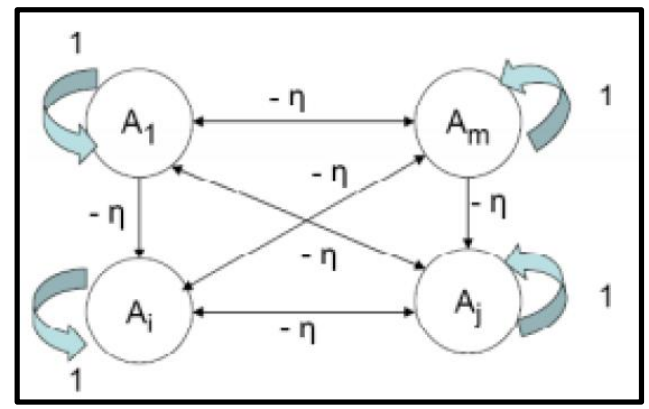

Gambar 4. Arsitektur Layar Kompetititif

\section{Backpropagation}

Pada bidang peramalan (forecasting) untuk pengaplikasinnya banyak menggunakan metode backpropagation. Dalam pengaplikasiannya backpropagation mendapatkan keseimbangan kemampuan jaringan mengenali pola selama pelatihan serta kemampuan jaringan dalam memberi tanggapan yang benar terhadap pola masukan yang serupa namun tidak sama dengan pola yang dipakai selama pelatihan [10].

Menurut Kusumadewi [9], dalam hal pelatihan metode backpropagation memiliki kesamaan dengan metode jaringan syaraf tiruan yang lain. Pelatihan dilakukan dalam proses perhitungan bobot yang pada akhir pelatihan akan didapatkan bobot-bobot yang baik pada jaringan umpan maju (feedforward). Untuk meminimumkan kasalahan (error), semua dilakukan selama proses pelatihan. Berdasarkan nilai rata-rata kesalahan kuadrat (MSE) akan dihitung menjadi kesalahan. Sebagai dasar perhitungan juga digunakan fungsi aktivasi dan rata-rata kuadrat kesalahan.

Dalam rangka meminimumkan kinerja dan bagaimana mengatur bobot-bobot tersebut, sebagian besar pelatihan jaringan feedfoward (umpan maju) menggunakan gradient dari fungsi aktivasi. Backpropagation merupakan suau teknik yang digunakan untuk menentukan gradient. Gradient negative merupakan dasar algoritma pelatihan standar backpropagation yang meggerakannya kearah sana. Memperbaiki bobot-bobot jaringan dengan arah yang membuat fungsi aktivasi menjadi turun dengan cepat merupakan prinsip dasar dari algoritma backpropagation. 


\section{E. Learning Vector Quantization}

Nurkhozin, dkk dalam penelitiannya menyebutkan learning vector quantization (LVQ) merupakan jaringan yang terdiri atas unit masukan dan unit keluaran dengan arsitektur lapis-tunggal umpan maju (Single Layer Feedforward) [2]. Menurut Kususmadewi mendefenisikan LVQ adalah metode yang melakukan pembelajaran pada lapisan kompetitif yang terawasi. Dalam mengkalisifikasikan vector-vektor input suatu lapisan kompetitif akan dengan cepat belajar, Jarak antara vector-vektor masukan akan mempengaruhi kelas-kelas yang didapatkan dari lapisan kompetitif. Secara cepat lapisan kompetitif akan meletekan kedua vektor kedalam kelas yang sama apabila kedua buah vektor masukan mendekati sama.

\section{F. Teknik Analisis Data.}

Model penelitian, kerangka teoritis dengan tahapan penelitian yang telah di formulasikan sebelumnya. Penelitian ini menggunakan metode komperatif dengan pendekatan kuantitatif, dimana penulis akan mencari metode yang memiliki tingkat keakurasian lebih tinggi dari kedua metode jaringan syaraf tiruan yang digunakan dalam penelitian ini. Data yang diperoleh dari hasil tes potensi (empat variable input dan target sebanyak dua kelas) yang telah dilakukan terhadap mahasiswa baru di STMIK PalComTech, kemudian data tersebut di training dengan kedua metode tersebut. Setelah data ditraining kemudian data tersebut di testing menggunakan variasi parameter tentutnya data training da testing telah di kalsifikasikan sebelumnya.

Sebelum dilakuakan perbandingan data yang didapat dari hasil tes potensi akan dinormalisasikan dengan menggunakan rumus sebagau berikut, Hasim [15] :

$$
x^{\prime}=\frac{X-X_{\min }}{X_{\max }-X_{\min }} x(B A-B B)+B B
$$

Dengan penjelasan sebagai berikut:

$x^{\prime}=$ nilai data ke-n (setelah dilakukan normalisasi data)

$x=$ nilai data ke-n

$x_{\max }=$ nilai data yang tertinggi

$x_{\min }=$ nilai data yang terendah

$$
\begin{aligned}
x & =\text { nilai data ke-n } \\
B A & =\text { Batas Atas (1) }
\end{aligned}
$$

$$
B B=\text { Batas Bawah (0) }
$$

Dengan hasil akhir presentasi akurasi dapat dilakukan dengan rumus sembagai berikut ini:

persentase akurasi $=$

$$
\frac{\text { Jumlah data valid }}{\text { Jumlah data yang diuji }} \times 100 \%
$$

Dalam proses perhitungan, penuli menggunakan MatLab (Matrix Laboratory). Semakin rendah nilai error yang didapat makan akan semakin kecil keselahan hasil tes prediksi yang diinnginkan. Sehingga akurasi prediksi hasil pelatihan akan semakin tinggi.

\section{HASIL DAN PEMBAHASAN}

Hasil perbandingan metode backpropagation dan $L V Q$ ditentukan dengan menggunakan arsitektur jaringan syraf tiruan yang dirancang dari kedua metode dengan menggunakan sebanyak 3 (tiga) variasi dalam pelatihan data training dan pengujian testing. Selain menggunakan variasi data latih dan data uji, untuk mencari hasil yang lebih optimal oleh jaringan syaraf tiruan maka penulis menggunakan variasi nilai $\alpha$ (learning rate). Table 1 menunjukan variasi learning rate, sebagai berikut:

Tabel 1. Variasi Learing rate

\begin{tabular}{|c|c|c|}
\hline No & Learning rate $(\alpha)$ & Epoch \\
\hline 1 & 0,5 & 100 \\
\hline 2 & 0,1 & 50 \\
\hline 3 & 1 & 20 \\
\hline
\end{tabular}

Pola yang diuji menggunakan Matlab merupakan pola yang telah detraining yang kemudian dilakukan pengujian. Penulis akan melakukan pengujian dengan menggunakan arsitektur masing-masing metode yakni backporpagation dan learning vector quantization. Tabel 2 menunjukan perbandingan terbaik dari kedua meode dalam melakukan pengenalan pola. 
Tabel 2 Hasil Perbandingan Kedua Metode

\begin{tabular}{|c|c|c|c|c|}
\hline \multirow{2}{*}{ Metode } & \multicolumn{2}{|c|}{$\begin{array}{c}\text { Pola yang } \\
\text { dikenali (latih) }\end{array}$} & \multicolumn{2}{c|}{$\begin{array}{c}\text { Pola yang } \\
\text { dikenali (uji) }\end{array}$} \\
\cline { 2 - 5 } & $\begin{array}{c}\text { Jumla } \\
\mathrm{h} \\
\text { berha } \\
\text { sil }\end{array}$ & $\begin{array}{c}\text { Jumla } \\
\mathrm{h} \\
\text { tidak } \\
\text { berha } \\
\text { sil }\end{array}$ & $\begin{array}{c}\text { Jumla } \\
\mathrm{h} \\
\text { berha } \\
\text { sil }\end{array}$ & $\begin{array}{c}\text { Jumla } \\
\mathrm{h} \\
\text { tidak } \\
\text { berha } \\
\text { sil }\end{array}$ \\
\hline $\begin{array}{c}\text { Backpropaga } \\
\text { tion }\end{array}$ & 89 & 1 & 30 & 0 \\
\hline LVQ & 87 & 3 & 29 & 1 \\
\hline
\end{tabular}

Setelah didapatkan hasil yang paling baik dari pengujian menggunakan kedua metode jaringan syaraf tiruan, langkah selanjutnya adalah membandingkan hasil yang didapt dari kedua metode. Variabel data uji dan data latih terbaik yang didapat dari kedua metode jaringan syaraf tiruan adalah 90 data latih dan 30 data uji, ini membuktikan semakin tinggi/banyak data latih yang digunakan maka jaringan syaraf tiruan dalam mengenali pola akan semakin baik. Berdasarkan varibel terbaik yang digunakan, metode jaringan syaraf tiruan backpropagation berhasil mengenali pola atau tingkat akurasinya mencapai $99,17 \%$, berbeda halnya dengan metode jaringan syaraf tiruan $L V Q$ yang hanya mencapai 96,67\%. Kemudian variasi learning rate dan epoch terbaik untuk metode jaringan syaraf tiruan backpropagation adalah learning rate $=0,1$ dan epoch $=100$, sementara untuk jaringan syaraf tiruan LVQ adalah learning rate $=1$ dan epoch $=20$.

Berdasarkan hasil pengejuian yang dilakukan, dapat direkomendasikan metode yang lebih baik untuk menggali potensi mahasiswa baru di STMIK PalComTech dari segi akurasi adalah metode backpropagation.

\section{SIMPULAN DAN SARAN}

\section{A. SIMPULAN}

Hasil pengujian perbandingan metode backpropagation dan learning vector quantization dalam menggali potensi mahasiswa baru di STMIK PalComTech didapatkan kesimpulan:
1. Dari hasil pengujian menggunakan kedua metode jaringan syaraf tiruan (backpropagation dan learning vector quantization) didapatkan metode jaringan syaraf tiruan backpropagation yang paling tepat diterapkan dalam menggali potensi mahasiswa baru di STMIK PalComTech, Ini dibuktikan dari tingkat akurasi yang didapat dari metode backproagation adalah $99,17 \%$, lebih besar dibandingkan metode $l v q$ yang hanya mencapai tingkat akurasi sebesar $96,67 \%$.

2. Berdasarkan hasil pengujian dengan menggunakan kedua metode jaringan syaraf tiruan, hasil variasi parameter terbaik yakni learning rate $=0,1$ dengan jumlah epoch $=$ 100 untuk metode backpropagation sedangkan learning rate $=1$ dan jumlah epoch $=20$ untuk metode learning vector quantization.

\section{B. SARAN}

Dari hasil pengujian dalam membandingkan hasil penggalian potensi mahasiswa baru di STMIK PalComTech menggunakan metode jaringan syaraf tiruan (backpropagation dan learning vector quantization) adapun saran yang dapat dimuat dalam penulisan ini:

1. Dalam penelitian ini ruang lingkup hanya dikhususkan untuk mahasiswa di lingkungan Sekolah tinggi yang memiliki dua program studi saja. Saran dari penulis penelitian lebih lanjut dapat dikembangkan dengan program studi yang lebih banyak lagi, misalnya dilakukan dalam tingkat universitas.

2. Untuk mendapatkan perbandingan yang lebih baik, disarankan pada penelitian selanjutnya untuk membandingan metode jaringan syaraf tiruan yang lain, mislanya menggunakan metode Perceptron.

3. Luaran dari penelitian ini masih sebatas rekomendasi metode terbaik yang digunakan, akan lebih baik jika diterapkan kedalam sebuah aplikasi dengan data yang telah didapat oleh penulis. 


\section{UCAPAN TERIMAKASIH}

Ucapan terimakasih penulis sampaikan kepada kepada STMIK PalComTech dan Program Pascasarjana Universitas Bina Darma yang telah terlibat dalam penelitian ini, penulis juga mengucapkan terima kasih kepada kedua orang tua yang telah memberikan dukungan moril terhadap penelitian ini serta kepada dosen yang telah membagikan ilmu kepada peneliti.

\section{REFERENSI}

[1] H. Andik Asmara, "Pengembangan Tes Minat Dan Bakat Dengan Metode Jaringan Syaraf Tiruan ( Jst ) Untuk Memprediksi Developing Interest and Talent Test Using Artificial Neural Network ( Ann ) To Predict Students ' Aptitude," J. Pendidik. Vokasi, vol. 5, pp. $1-14,2015$.

[2] a. Nurkhozin, M. I. Irawan, and I. Mukhlash, "Klasifikasi Penyakit Diabetes Mellitus Menggunakan Jaringan Syaraf Tiruan Backpropagation Dan Learning," Pros. Semin. Nas. Penelitian, Pendidik. dan Penerapan MIPA, no. 7, pp. 1-8, 2011.

[3] M. F. Q. Azizi, "Perbandingan antara Metode Backpropagation dengan Metode Learning Vector Quantization (LVQ) pada Pengenalan Citra Barcode." Universitas Negeri Semarang, 2013.

[4] A. Prabowo, E. A. Sarwoko, and D. E. Riyanto, "Learning Vector Quantization Pada Pengenalan Pola Tandatangan," $J$. SAINS DAN Mat., vol. 14, no. 4, pp. 147-153, 2006.

[5] R. Meliawati, O. Soesanto, and D. Kartini, "Penerapan Metode Learning Vector Quantization (LVQ) Pada Prediksi Jurusan Di SMA PGRI 1 Banjarbaru," KLIK-KUMPULAN J. ILMU Komput., vol. 3, no. 1, pp. 11-20, 2016.

[6] D. Kartini, R. A. Nugroho, and M. R. Faisal, "Klasifikasi Kelulusan Mahasiswa Menggunakan Algoritma Learning Vector Quantization," POSITIF
J. Sist. dan Teknol. Inf., vol. 3, no. 2, pp. 93-98, 2017.

[7] D. A. Nugraha and W. Retnowati, "Sistem Pendukung Keputusan Penjurusan di SMA Menggunakan Metode Neural Network Backpropagation (Studi Kasus SMA Islam Kepanjen Malang)," Bimasakti.

[8] A. Jumarwanto, R. Hartanto, and D. Prastiyanto, "Aplikasi jaringan saraf tiruan backpropagation untuk memprediksi penyakit THT di Rumah Sakit Mardi Rahayu Kudus," J. Tek. Elektro, vol. 1, no. 1, p. 11, 2009.

[9] S. Kusumadewi, "Artificial intelligence (teknik dan aplikasinya)," Yogyakarta Graha Ilmu, vol. 5, 2003.

[10] J. J. Siang, "Jaringan syaraf tiruan dan pemrogramannya menggunakan Matlab," Penerbit Andi, Yogyakarta, 2005.

[11] D. Puspitaningrum, "Pengantar Jaringan Syaraf Tiruan," 2006.

[12] L. V Fausett, Fundamentals of neural networks: architectures, algorithms, and applications, vol. 3. prentice-Hall Englewood Cliffs, 1994.

[13] Y. A. Lesnussa, S. Latuconsina, and E. R. Persulessy, "Aplikasi Jaringan Saraf Tiruan Backpropagation untuk Memprediksi Prestasi Siswa SMA (Studi kasus: Prediksi Prestasi Siswa SMAN 4 Ambon)," J. Mat. Integr. ISSN, vol. 1412, p. 6184, 2015.

[14] Y. A. Lesnussa, L. J. Sinay, and M. R. Idah, "Aplikasi Jaringan Saraf Tiruan Backpropagation untuk Penyebaran Penyakit Demam Berdarah Dengue (DBD) di Kota Ambon," J. Mat. Integr., vol. 13, no. 2, pp. 63-72, 2017.

[15] A. Hasim, "Prakiraan Beban Listrik Kota Pontianak Dengan Jaringan Syaraf Tiruan (Artificial Neural Network)." IPB, Bogor (Tesis S2), 2008. 